Jurnal Indonesia Sosial Teknologi: p-ISSN: 2723 - 6609

e-ISSN: 2745-5254

Vol. 2, No. 1, Januari 2021

\title{
STRATEGI ADAPTASI NELAYAN DI KENJERAN, KECAMATAN SUKOLILO LARANGAN, KABUPATEN SURABAYA, PROVINSI JAWA TIMUR DALAM MENGHADAPI EKOLOGINYA
}

\author{
Ni Nengah Dea Ayu Ferina \\ Universitas Indonesia \\ Email: ninengahdea@gmail.com
}

\begin{abstract}
The resources that exist in coastal Indonesia are faced with two conditions. First, there are areas that have not been touched by development activities. Second, there are areas that have been greatly utilized. This research was conducted to study fishermen's adaptation strategies in dealing with ecological changes in the coastal area of Kenjeran Beach, Sukolilo Larangan District, Surabaya Regency, East Java Province. The method in conducting this research is qualitative by collecting interview data and field observations. The results showed that there were several adaptation strategies applied by Kenjeran fishermen's household life to meet their daily needs with changing ecological conditions due to natural fluctuations and the construction of Surabaya bridges. Kenjeran fisherman households carry out various kinds of adaptation options according to the resources owned by Kenjeran fishermen, based on the results of observations at the research location, the adaptations made by fishermen include: diversifying jobs, diversifying fishing gear, utilizing social relationships, and household mobilization.
\end{abstract}

Keyword : adaptation strategy; fisherman; ecological change.

Abstrak

Sumber daya yang ada di pesisir Indonesia dihadapkan pada dua kondisi. Pertama, adanya kawasan yang belum tersentuh oleh aktivitas pembangunan. Kedua, terdapat adanya kawasan yang sudah dimanfaatkan secara besar. Penelitian ini dilakukan untuk mengkaji strategi adaptasi nelayan dalam menghadapi perubahan ekologi di kawasan pesisir pantai Kenjeran, Kecamatan Sukolilo Larangan, Kabupaten Surabaya, Provinsi Jawa Timur. Metode dalam melakukan penelitian ini adalah dengan cara kualitatif dengan mengumpulkan data wawancara dan obervasi lapangan. Hasil penelitian menunjukan bahwa terdapat beberapa strategi adaptasi yang diterapkan oleh kehidupan rumah tangga nelayan Kenjeran guna memenuhi kebutuhan sehari-harinya dengan kondisi ekologi yang berubah-ubah diakibatkan karena fluktuasi alam dan pembangunan jembatan Surabaya. Rumah tangga nelayan Kenjeran melakukan berbagai macam pilihan adaptasi sesuai sumberdaya yang dimiliki oleh nelayan Kenjeran. Berdasarkan hasil observasi di lokasi penelitian, adaptasi yang dilakukan oleh nelayan antara lain: (1) melakukan diversifikasi pekerjaan; (2) penganekaragaman alat tangkap; (3) memanfaatkan hubungan sosial; dan (4) mobilisasi rumah tangga. 
Kata kunci: strategi adaptasi; nelayan; perubahan ekologi.

\section{Pendahuluan}

Indonesia memiliki wilayah laut yang sangat luas, lebih luas daripada wilayah darat. Dalam wilayah laut juga terdapat sumberdaya yang memiliki potensi yang sangat tinggi, yang dapat dimanfaatkan untuk menjamin kesejahteraan kehidupan nelayan dan keluarganya. Kemiskinan merupakan fenomena yang sering terjadi khususnya di masyarakat perkotaan. Kemiskinan di perkotaan ditandai dengan beberapa ciri yaitu sulit untuk memenuhi sandang dan pangan, tempat tinggal yang berada dibawah jembatan, serta wilayah tempat tinggal yang kumuh. Kemiskinan terjadi karena adanya proses urbanisasi yang dianggap bahwa kehidupan di kota menyediakan banyak lowongan pekerjaan, namun hal ini sulit menjadi proses adaptasi orang desa yang pergi ke kota karena orang desa tidak memiliki keterampilan yang digunakan untuk bertahan di perkotaan, maka hal ini dapat menjadikan kondisi kemiskinan.

Dari penjelasan kemiskinan yang terjadi karena pendapatan yang diterima oleh seseorang tersebut kurang mencukupi kebutuhan pokok mereka sehingga terkadang mereka mencari solusi tersebut dengan mengemis namun ada juga yang menjual barang-barang bekas. Tempat tinggal mereka terkadang juga tidak menentu, ada juga yang tinggal di dekat rongsokan, di bawah jembatan, di emperan toko dan lain-lain, biasanya hal ini terjadi pada daerah perkotaan. Penyebab terjadinya kemiskinan di kota adalah pekerjaan yang kurang diperhatikan oleh pemerintah, yaitu petani dan nelayan. Padahal pekerjaan mereka sangat dibutuhkan di negara yang kaya akan sumber daya alam lautan dan tanah yang bisa ditanam oleh beribu-ribu pohon, biji-bijian, padi dan lain-lain. Pekerjaan ini seringkali diremehkan sehingga pendapatan yang dihasilkan oleh petani dan nelayan terkadang kurang mencukupi kehidupan mereka. Untuk mengatasi permasalahn kemiskinan pada nelayan pemerintah memberikan kredit motorisasi kepada nelayan, namun ternyata program ini menjadikan bumerang bagi para nelayan (Retno, 2016).

Nelayan bukanlah sesuatu yang tunggal, melainkan terdiri dari beberapa kelompok. Pengelompokan nelayan dapat ditinjau dari segi kepemilikan alat tangkap dapat dibedakan menjadi tiga kelompok, yaitu: (1) nelayan buruh; (2) juragan; dan (3) nelayan perorangan. Nelayan buruh adalah nelayan yang bekerja menggunakan alat tangkap milik orang lain. Juragan adalah nelayan yang memiliki alat tangkap yang dioperasikan oleh orang lain. Adapun nelayan perorangan adalah nelayan yang mempunyai alat tangkap sendiri dan dalam pengoperasiannya tidak melibatkan orang lain. Dari ketiga jenis nelayan tersebut, pada umumnya kelompok nelayan juragan dalam keadaan ekonomi yang baik. Kemiskinan cenderung dialami oleh nelayan perorangan dan buruh nelayan. Oleh karena itu kedua jenis kelompok nelayan itu jumlahnya mayoritas, maka citra tentang kemiskinan melekat pada kehidupan nelayan (Imron, 2003). Untuk mengatasi kemiskinan yang dialami oleh nelayan maka perlu adanya perhatian dari pemerintah terhadap nelayan seperti memberikan kredit motorisasi pada nelayan (Retno, 2016).

Secara geografis masyarakat nelayan merupakan masyarakat yang tumbuh dan berkembang di wilayah pesisir, yaitu di kawasan antara daratan dan lautan (Kusnaidi 2008:27). Nelayan merupakan pekerjaan yang tepat bagi negara Indonesia yang sebagian besar wilayahnya adalah lautan. Namun faktanya nelayan Indonesia masih tergolong miskin. Sebenarnya melihat dari kondisi Indonesia yang dikelilingi oleh lautan maka nelayan merupakan pekerjaan yang seharusnya lebih sejahtera (H. 
Hamdani \& K. Wulandari, 2013). Secara geografis negara Indonesia terbagi menjadi ribuan wilayah, dimana setiap wilayah masing-masing memiliki potensi Sumber Daya Alam dan Sumber Daya Manusia, seperti halnya pantai Kenjeran. Pantai yang terletak di kota Surabaya ini, merupakan salah satu pantai yang membatasi kota Surabaya dengan Madura dan termasuk salah satu ikon wisata kota Surabaya (Hardiyanti, 2016).

Nelayan pada umumnya bekerja di desa-desa namun berbeda dengan nelayan yang ada di Kenjeran yang kerjanya di tengah kota metropolitan. Kenjeran ini berada di kota Surabaya yang berdekatan dengan pulau Madura. Di sini terdapat kehidupan nelayan yang tergolong tingkat perekonomiannya rendah dan sulit untuk memenuhi kehidupannnya sendiri. Kehidupan di perkotaan biaya hidup tegolong tinggi dan kebutuhan serba mahal, dengan kondisi perekonomian nelayan yang tidak pasti dan pendapatan yang tidak menentu. Sehingga hal ini mengakibatkan kehidupan nelayan serba kekurangan, dan nelayan harus beradaptasi dengan lingkungan perkotaan.

Adaptasi serta perubahan merupakan dua hal yang tidak dapat dipisahkan dari makhluk hidup. Adaptasi berhubungan bagi semua makhluk hidup dalam menjalani kehidupannya yang seiring selalu berubah (Bennet, 1976). Memandang adaptasi sebagai suatu respon perilaku manusia terhadap lingkungan yang tidaklah tetap. Perilaku ini mengatur sistem tertentu bagi tindakan atau tingkah lakunya agar dapat menyesuaikan diri dengan situasi kondisi yang ada. Perilaku ini berkaitan dengan kebutuhan hidup, setelah melewati keadaan-keadaan sebelumnya dan selanjutnya membentuk suatu strategi serta keputusan untuk menghadapi keadaan yang akan datang.

Adaptasi merupakan hal dari bagian proses evolusi kebudayaan, yaitu proses yang mencakup usaha manusia untuk menyesuaikan diri atau memberi respon pada perubahan lingkungan fisiknya atau sosial yang terjadi. Menjelaskan bahwa asumsi dasar adaptasi berkembang dari pemahaman yang bersifat evolusionari yang melihat menusia berupaya untuk menyesuaikan dirinya dengan lingkungannya, baik secara biologis atau genetik maupun secara sosial dan budaya. Sehingga proses adaptasi dalam evolusi melibatkan genetic dan varian budaya yang dianggap sebagai jalan terbaik untuk menyelesaikan permasalahan ekologinya.

Membedakan antara adaptive behaviour (perilaku adaptif) dengan adaptive strategies (strategi adaptif) dan adaptive processes (proses adaptif). Adaptive behaviour melihatkan pada cara dimana masyarakat dalam merencanakan memperoleh sumberdaya untuk mencapai sebuah tujuan dan memecahkan masalah. Adaptive behaviour merupakan suatu pilihan tindakan dengan mempertimbangan biaya yang harus dikembangkan dan hasil yang akan dicapai. Adaptive strategies merupakan pola umum yang terbentuk melalui penyesuaian pemikiran masyarakat secara terpisah. Dimana masyarakat merespon sebuah permasalahan yang dihadapi dengan melakukan sebuah cara dengan mempertimbangkan konsekuensinya. Adaptive process adalah perubahan yang ditujukan melalui proses yang panjang dengan menyesuaikan strategi yang dipilih.

Batas ekologi manusia merupakan sebuah kemampuan manusia untuk melakukan sebuah self objectification, yaitu belajar serta mengantisipasi. Manusia memiliki intelektual dalam merasakan serta menerima informasi untuk membentuk dirinya sendiri agar dapat bertindak pada lingkungan sekitarnya. Bedasarkan konsep adaptasi Bennet dinyatakan bahwa adaptasi sebagai suatu konsep umum yang dikaitkan pada proses penyesuaian terhadap keadaan yang berubah. Begitu juga pada nelayan dimana mereka menyesuaikan dirinya terhadap keadaan ekologinya yang berubah 
sehingga membuat nelayan melakukan sebuah strategi adaptasi dalam memenuhi kebutuhan sehari-harinya. Terdapat sebuah penelitian terdahulu yang berkaitan dengan kehidupan nelayan dengan ekologinya sebagai berikut.

(Wiyono, 2008) meneliti strategi nelayan Cirebon Jawa Barat dimana dikatakan bahwa melihat cara nelayan dalam memutuskan pengoperasian alat tangkapnya dimana nelayan perlu mengetahui pola adaptasi nelayan terhadap perubahan lingkungan diluar usahanya. Adaptasi yang dihadapi oleh nelayan Cirebon adalah mencakup pada adaptasi dalam kenaikan BBM pada kapal yang digunakan, adaptasi menghadapi peningkatan biaya usaha penangkapan, adaptasi menghadapi penurunan pendapatan usaha penangkapannya. Namun berbeda halnya yang dilakukan oleh (Nurisnaeny, 2016) meneliti tentang adaptasi nelayan kawasan perbatasan di Desa Sei Pancang Kecamatan Sebatik Utara Kabupaten Nunukan Provinsi Kalimantan Timur dimana pada penelitian ini terdapat adanya hubungan lintas negara baik dalam kehidupan sosial maupun ekonomi dari penduduk yang tinggal di Desa Sei Pancang (Indonesia) ke Kota Tawau (Malaysia) melalui jalur laut, hal ini menjadikan masyarakat Desa Sei sendiri harus beradaptasi dengan lingkungannya dengan adanya perbatasan Negara saat mencari ikan.

(Surur, 2015) yang meneliti tentang strategi adaptasi nelayan terhadap perubahan ekologi Danau Tempe di Desa Pallime Kecamatan Sabbangparu Kabupaten Wajo. Dalam tulisan penelitian ini terdapat perubahan ekologi yang diakibatkan karena pendakalan dan pencemaran yang dirasakan oleh nelayan sehingga menyebabkan penurunan hasil tangkapannya. Dengan perubahan ekologi yang dirasakan oleh nelayan Desa Pallime menjadikan nelayan harus beradaptasi dengan keadaan yang dirasakannya, adaptasi yang dilakukan oleh nelayan Desa Pallime adalah dengan adanya pengakenaragaman pendapatan, pemanfaatan hubungan sosial, memobilisasi anggota rumah tangga, perubahan daerah tangkapan, dan memanfaatkan teknlogi tradisional.

Namun dengan studi kajian terdahulu yang sudah diuraikan diatas tentang kajian adaptasi, hal yang belum di bahas dalam keterkaitan dengan penelitian ini adalah untuk mengetahui bagaimana bentuk strategi adaptasi nelayan di Kenjeran dalam memenuhi kebutuhan hidupnya pada ekologisnya yang ditengah perkotaan Surabaya dimana di Kenjeran ini terdapat adanya pembangunan jembatan di tengah laut yang berdampak pada ekologi serta perekonomian nelayan dalam memenuhi kebutuhan hidupnya untuk beradaptasi pada kondisi ekologi yang ada saat ini. Sehingga dalam penelitian ini tujuannya untuk memgetahui kehidupan nelayan Kenjeran yang dimana dalam memenuhi kebutuhannya masih serba kekurangan walaupun dilakukannya strategistrategi yang sudah dilakukan oleh para nelayan Kenjeran.

\section{Metode Penelitian}

Penelitian ini menggunakan metode kualitatif yang digunakan untuk mengetahui lebih banyak kehidupan sosial ekonomi nelayan yang berkaitan dengan ekologinya serta mengetahui strategi adaptasi yang dilakukan nelayan dalam memenuhi kehidupannya dengan keadaan lingkungannya. Pendekatan yang digunakan dalam penelitian ini adalah deskriptif. Penelitian deskriptif berguna untuk penjelasan menjadi lebih sistematis, faktual, dan akurat mengenai fakta-fakta yang ada. Strategi penelitian yang digunakan dalam penelitian ini adalah studi kasus. Kasus yang dipilih dalam penelitian ini adalah strategi adaptasi nelayan Kenjeran terhadap ekologisnya yang berada di tengah perkotaan Surabaya. Pengambilan data yang dilakukan dalam penelitian ini dengan cara observasi serta wawancara langsung pada informan. 
Penelitian ini dilakukan di jl. Kenjeran, Kecamatan Sukolilo Larangan, Surabaya, Provinsi Jawa Timur. Pemilihan lokasi ini dilakukan secara sengaja karena dengan lokasi di Kenjeran Surabaya ini merupakan daerah pesisir yang ada di Kota Surabaya, dimana sebagian besar masyarakat di Kenjeran bermatapencaharian sebagai nelayan yang menggantungkan hidupnya hanya pada hasil laut yang mereka dapat pada sehari-hari.

Dalam pengumpulan data menggunakan data primer dan data skunder. Data primer yang diperoleh melalui teknik wawancara informan dengan menggunakan pedoman wawancara yang disiapkan. Sedangkan pengumpulan datanya dari informan yang dilakukan dengan wawancara mendalam menggunakan pedoman wawancara. Selain menggunakan data primer dalam penelitian ini juga menggunakan data sekunder yang merupakan data yang diperoleh dari buku, internet, jurnal penelitian yang kaitannya dengan penelitian ini.

Dalam teknik analisis data dilakukan sejak awal melakukan pengumpulan data. Hasil dari wawancara mendalam dan pengamatan (observasi) disajikan dalam bentuk catatan harian yang dianalisis sejak pertama kali datang ke lapangan dan berlangsung secara terus menerus yang terdiri dari pengumpulan data, analsis data, penyajian data, dan penarikan kesimpulan.

\section{Hasil dan Pembahasan}

Pada saat ini masalah kemiskinan bukan hanya menjadi isu sosial yang dibicarakan dengan lebih mengedepankan rasa kemanusiaan, namun juga telah menjadi isu politik yang dipakai sebagai dasar untuk menilai kinerja pemerintahan. Secara sosiologis, kemiskinan sesungguhnya bukanlah hal kurangnya pendapatan untuk memenuhi kebutuhan hidup pokok atau standar hidup layak, tetapi lebih dari itu kemiskinan merupakan hal yang mengaitkan kemungkinan orang atau keluarga miskin itu untuk melangsungkan taraf kehidupannya. Studi yang dilakukan oleh Wigrjosorbroto dkk (1992) tentang kehidupan masyarakat di Kota Surabaya menemukan bahwa seseorang atau sebuah keluarga yang dijajah kemiskinan, mereka umumnya tidak berdaya, kehidupannya serba kurang, dan cenderung sulit untuk telibat kedalam sektor - sektor yang membuat mereka dapat menjadikan dirinya ke tingkatan hidup yang sejahterah, sedangkan untuk bertahan daam kehidupan fisiknya pada tingkatan yang tersistem bagi keluarga miskin hampir menjadi sebuah hal yang tidak mungkin bila tidak ditopang oleh jaringan dan pranata sosial di lingkungan sekitarnya. Faktor yang disebabkan timbulnya kemiskinan diantaranya; rendahnya tingkat pendidikan, rendahnya derajat kesehatan, terbatasnya lapangan kerja, dan kondisi keterisolasian

Secara umum nelayan diartikan sebagai orang yang matapencahariaannya mencari ikan, penangkap ikan dilaut. Nelayan adalah aktivitas dari manusia/ kelompok yang kehidupannya bergantung langsung pada hasil laut, baik itu dengan cara menangkap atau dengan membudidaya. Kelompok ini bertempat tinggal di pesisir pantai, dimana lokasinya berdekatan langsung dengan lautan atau pantai yang memang sesuai dengan kegiatannya sehari-hari. Kawasan pesisir pantai yang seharusnya kaya akan sumberdaya perikanan dan biota laut yang mayoritas penduduknya merupakan nelayan seharusnya mereka tidak tergolong pada kelompok masyarakat miskin, namun faktanya merekalah yang sebagian besar merupakan kantong-kantong kemiskinan. Dari waktu ke waktu masyarakat nelayan ini melawan ketidakpastian hidup terlebih pada 
nelayan yang melaut ke lautan bebas. Saat mereka dilanda musim angin barat maka nelayan ini tidak bisa mendapatkan penghasilan sama sekali. Alhasil keluarga mereka mengalami ketidak cukupan untuk bertahan hidup. Dengan hal ini keluarga nelayan bekerjasama untuk mencari penghasilan tambahan dengan mencari pekerjaan lain diluar melaut (Tain, 2013).

Menurut Acheson dalam (Andrianti, 2012) kelompok masyarakat nelayan atau masyarakat yang tinggal di pesisir pantai ini mengalami kehidupan yang kurang sejahtera hal ini di karenakan adanya gangguan fluktuasi alam dimana pada saat musim angin barat biasanya terjadi cuaca buruk dimana adanya ombak besar, angin kencang, badai dan harga ikan di pasaran yang terjerat tengkulak. Menurut (Retno, 2016) jika dibandingkan dengan kelompok masyarakat lain, kelompok petani dan nelayan ini termasuk dalam lapisan kelompok sosial yang paling miskin, namun sebagian nelayan juga tidak bisa dikatakan miskin. Pada umunya kelompok nelayan yang kaya atau biasa disebut dengan juragan ini mereka akan melakukan gaya hidup yang konsumtif dimana penghasilan mereka diatas rata-rata nelayan tradisional, mereka bisa membelanjakan uang mereka sesuai keperluan mereka namun terkadang bukan kebutuhan pokok atau primer (Hamdani, 2013).

Di Surabaya tepatnya di pantai Kenjeran yang merupakan ikon kota Surabaya ini membuat pemerintah semakin berbenah untuk melakukan perbaikan, pembenahan, dan pembangunan area wisata pantai ria ini. Dengan adanya permasalahan yang ada saat ini dikarenakan Covid-19 membuat pengunjung wisatawan pantai Kenjeran ini tidak seramai biasanya. Hal ini membuat nelayan Kenjeran harus beradaptasi dengan adanya kondisi saat ini dan juga faktor ekologi yang ada disekelilingnya. Penghasilan nelayan Kenjeran Surabaya yang tidak menentu dikarenakan adanya faktor fluktuasi alam ditambah lagi dengan kondisi permasalahan Covid-19 yang tak kunjung selesai pula. Para nelayan Kenjeran mengklaim dirinya sama saja kondisi sebelum Covid dan saat Covid, penghasilan mereka tetap tidak menentu dan penghasilannya pun sama, hal ini dikarenakan masalah-masalah sosial yang mereka hadapi, seperti harus membayar hutang mereka, memenuhi kebutuhan hidup sehari-hari, biaya sewa perahu (bagi kelompok nelayan yang tidak memiliki perahu), dan membeli bensin untuk perahunya.

Mayoritas nelayan Kenjeran merupakan nelayan tradisional. Berdasarkan pengertian nelayan tradisional adalah nelayan yang bekerja menggunakan perahu dan alat tangkap yang sederhana. Nelayan Kenjeran merupakan nelayan pantai yang dapat pulang setiap harinya. Nelayan Kenjeran dikatakan sebagai nelayan tradisional karena ia juga menangkap ikan dengan jarak kurang lebih 4 mil, karena kondisi perahu yang digunakan adalah perahu sederhana dan kecil. Dalam memenuhi kebutuhan hidupnya nelayan Kenjeran memiliki strategi sendiri.

barang dalam rumah dijual nanti bisa dapet lagi beli lagi jadi kalo kata lagu itu seperti "gali lubang tutup lubang” gitu lho jadi nanti musim ini dijual punya emas ya di jual untuk apa? untuk buat makan nanti kalo dapet lagi ya beli lagi gitu lho." (Bapak Muslimin, 50 Tahun)

Dalam kehidupan perekonomian kehidupan nelayan terbilang sangat kurang, karena dalam pendapatan kehidupannya tidak pasti dalam setiap harinya dan bergantung cuaca. Pekerjaan sebagai nelayan tradisional hanya menggunakan alat tangkap yang ada sehingga nelayan Kenjeran sulit untuk memenuhi kebutuhan hidupnya. Dari kacamata nelayan Kenjeran mengatakan bahwa hidupnya bagaikan "gali lubang tutup lubang". Mereka memanfaatkan barang atau harta benda yang ada di rumahnya untuk dapat menutup kekurangan dalam memenuhi kebutuhan hidupnya dengan cara dijual. Bagi 
mereka (nelayan) barang / atau harta benda yang ada dirumah dianggap mudah untuk di dapat, dengan menjual barang ia dapat membelinya kembali saat memiliki pendapatan yang lebih. Namun hal tersebut sulit dipungkiri bahwasanya dengan cara tersebut tetap saja hidupnya serba kekurangan karena kehidupan diperkotaan tidaklah mudah.

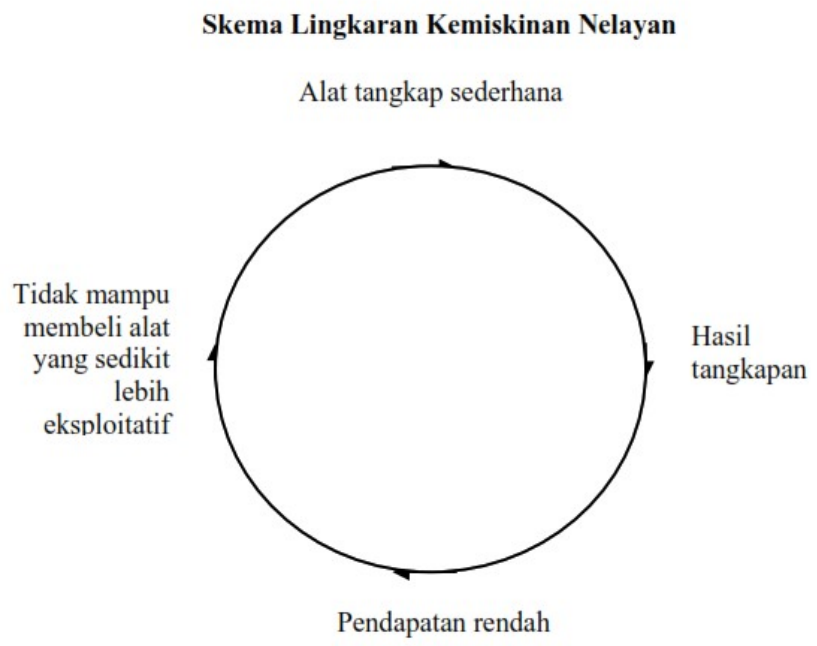

Kemiskinan yang dialami nelayan merupakan kemiskinan struktural (Andrianti, 2012). yang dimaksud dengan kemiskinan struktural adalah kemiskinan yang diderita oleh suatu golongan masyarakat, karena struktur sosial masyarakat itu tidak dapat ikut menggunakan sumber - sumber pendapatan yang seharusnya tersedia bagi mereka. Nelayan kenjeran bekerja untuk hidupnya namun ia tidak dapat merasakan hasilnya sendiri karena mereka menutup hutang yang ada pada juragan tersebut, hasil laut yang seharusnya mendapatkan lebih namun tidak dapat ia nikmati. Dengan roda kehidupan yang berputar seperti itu nelayan Kenjeran sulit dalam memenuhi kehidupannya, sehingga nelayan Kenjeran termasuk golongan kelompok miskin. Tidak hanya karena fluktuasi alam nelayan Kenjeran juga mengeluh atas alat tangkap yang mereka gunakan. Saat mereka pergi melaut hanya bisa dengan 4 mil, dan alat tangkap yang digunakan. Terdapat nelayan pula yang menggunakan alat yang lebih modern, namun mendapatkan hasil banyak. Dampaknya kepada nelayan tradisional adalah tidak mendapatkan hasil sebanyak nelayan yang menggunakan peralatan modern. Nelayan tradisional umumnya menggunakan alat sederhana yang ramah lingkungan. Nelayan yang menggunakan alat tidak ramah lingkungan mulai dilakukan pelarangan. Oleh karena itu kementrian kelautan mulai menggunakan pelarangan tersebut. Dengan kemiskinan yang dialami oleh nelayan Kenjeran sehingga mereka melakukan beberapa strategi adaptasi yang dilakukan guna memenuhi kebutuhan hidupnya selama sehari-hari.

\section{A. Diversifikasi Pekerjaan Sebagai Strategi untuk mempertahankan kelangsungan hidup}

Strategi adaptasi yang dilakukan oleh nelayan untuk mempertahankan kelangsungan hidup adalah dengan cara dilakumannya diversifikasi pekerjaan. Diversifikasi merupakan sebuah alternatif pilihan mata pencahariaan yang dilakukan oleh nelayan, baik dalam bidang perikanan maupun non perikanan. Beragam pekerjaan dapat dimasuki oleh mereka yang bergantung pada sumber daya yang tersedia di tempat nelayan tersebut. Menurut (Allison, 2001) mengatakan bahwa penganekaragaman dalam pendapatan merupakan pilihan yang tepat dengan tingginya sebuah masalah yang 
dialami nelayan dalam menghadapi fluktuasi musim ikan dan cuaca yang tidak menentu.

Masyarakat nelayan Kenjeran terbiasa dengan melakukan kerja sampingan untuk melakukan diversifikasi pekerjaan. Masyarakat nelayan Kenjeran tergolong nelayan tradisional, dengan teknologi penangkapan ikan yang sederhana sehingga ketergantungan kepada alam amat besar. Musim panen ikan hanya berlangsung sekitar tiga hingga empat bulan. Dalam kondisi semacam inilah nelayan sering menghadapi kesulitan dalam perekonomian, oleh karena itu melakukan pekerjaan sampingan disaat para nelayan ini tidak melaut merupakan hal yang lumrah apabila dilakukan. Kemampuan dan kemauan nelayan Kenjeran untuk melakukan kerja sampingan guna terpenuhinya kebutuhan hidupnya amat beragam. Ada nelayan yang terbiasa melakukan kerja sampingan yang dilakukan saat tidak melaut.

Nelayan Kenjeran melakukan diversifikasi pekerjaan dengan memanfaatkan perahunya untuk digunakan menjadi ojek pariwisata. Ojek pariwisata ini bentuk diversifikasi pekerjaan bagi kelompok nelayan Kenjeran. Ojek perahu pariwisata ini dilakukan oleh nelayan saat musim panen ikan sedang menurun, mereka melakukan pekerjaan ini dengan cara menawarkan para pengunjung wisata Pantai Ria Kenjeran dengan ongkos Rp. 5000 per-orang, dengan ongkos Rp. 5000 ini pengunjung diajak oleh nelayan Kenjeran berkeliling Pantai Ria sekaligus untuk melihat Pulau Pasir yang diklaim mengalami pendangkalan laut dikarenakan adanya pembangunan Jembatan Surabaya. Dengan kerja sampingan yang dilakukan, nelayan Kenjeran perharinya dapat mendapatkan uang hingga seratus seribu. Pekerjaan ini dilakukan sekedar untuk menutup kebutuhan hidup sehari-hari. Ketika kondisi laut sudah memungkinkan, mereka segera meninggalkan kerja sampingan untuk melaut. Ragam pekerjaan lain yang rutin adalah kegiatan yang masih terkait dengan perikanan, misalnya mengawetkan ikan atau mengasinkan ikan dan mencari teripang dipinggir pantai.

Penghasilan sebagai ojek perahu pariwisata biasanya dilakukan untuk menutup hutang yang ada di tengkulak/juragan. Juragan adalah orang yang memiliki hak atas kepemilikan perahu maupun alat tangkap. Perahu yang digunakan oleh nelayan Kenjeran bukanlah kepemilikan secara pribadi namun ada beberapa yang meminjam kepada orang yang disebut juragan. Tidak hanya meminjam perahu, nelayan juga meminjam uang kepada juragan untuk membiayai kebutuhan hidupnya dan biaya sekolah anak. Mereka tidak dapat memenuhi kebutuhan hidupnya secara baik karena roda kehidupan dimana saat memiliki uang digunakan untuk memenuhi hidupnya dan membayar hutang pada tengkulak, lalu saat mereka tidak memiliki uang mereka bekerja dengan melaut, saat melaut hasil laut tersebut dijual di juragan tersebut dan dipotong dengan uang hutang sebelumnya. Belum juga saat nelayan Kenjeran bekerja juga memerlukan biaya untuk membeli solar, minyak tanah, dan peralatan lampu yaitu sebagai tanggung jawab pemilik perahu.

“ Bu Saudah (isteri nelayan) Ya saya gak pernah dapet bantuan karena kan saya seorang perempuan mbak kayak perahu gitu.. suami saya kerjae darat jadi satpam aslie lho Cuma nelayan seng punya perahu tok seng dapet bantuan bantuan mesin jaring gitu"

Untuk nelayan yang meminjam perahu pada juragan, ia hanya menyumbang tenaga saja. Saat adanya bantuan dari pemerintah yang mendapat keuntungan yaitu bagi pemilik perahu saja namun nelayan yang meminjam tersebut tidak mendapat bantuan. Rendahnya keterampilan nelayan untuk melakukan diversifikasi kegiatan penangkapan 
dan keterikatan yang kuat terhadap pengoperasian satu jenis ala tangkap telah memberikan kontribusi terhadap timbulnya kemiskinan nelayan.

Kegiatan ini berjalan bukan tanpa hambatan. Hambatan yang datang dari kondisi lingkungan pesisir pantai Kenjeran. Kondisi pendangkalan pantai yang disebabkan oleh pembangunan jembatan membuat nelayan susah saat melakukan ojek perahu wisata karena nelayan harus menarik perahunya dengan membawa beban penumpang yang banyak. Selain hambatan yang dirasakan pada saat ojek perahu wisata, ada pula hambatan yang dirasakan saat mencari teripang di tepian pantai Kenjeran yang dikarenakan banyaknya lumpur sehingga kesusahan untuk mencari teripang.

\section{B. Memanfaatkan Hubungan Sosial}

Strategi adaptasi dengan memanfaatkan hubungan sosial merupakan salah satu strategi adaptasi rumah tangga nelayan Kenjeran guna memenuhi kehidupan sehari-hari. Strategi hubungan sosial yang umum dilakukan pada kelompok nelayan ditujukan untuk memenuhi kebutuhan dibidang kenelayanan (missal pemasaran hasil untuk memenuhi kebutuhan pokok). Semua rumah tangga nelayan memiliki hubungan sosial yang bersifat informal. Menurut (Alfiasari, 2009) jaringan informal ini menjadi adanya kepercayaan dan hubungan satu sama lain yang lebih umum dan bersifat personal. Ikatan yang lebih umum dan personal ini dijadikan hubungan sosial antar rumah tangga sehingga menjadi lebih dekat. Sehingga hubungan sosial tersebut dapat menjadikan untuk mencari hal yang luas dalam mengoptimalkan sumberdaya yang ada dalam hal meningkatkan kesejahteraan rumah tangga nelayan Kenjeran.

Pada kelompok nelayan terdapat hubungan patron-klien yang terjadi pada hubungan sosialnya. Peran patron yaitu pengepul hasil tangkapan nelayan, sedangkan peran klien yaitu kelompok nelayan itu. Hubungan patron-klien yang dijalankan oleh nelayan Kenjeran dibentuk karena adanya kepentingan yakni hubungan yang bertujuan tertentu atau tujuan khusus. Tujuan keduanya dalam menjalani hubungan patron-klien ini adalah untuk mendapatkan keuntungan berupa barang dan jasa atau sumberdaya lain yang tidak dapat diperoleh melalui cara lain atas pengorbanan yang telah diberikan. Patron memiliki tujuan untuk mendapatkan hasil tangkapan nelayan dengan harga murah dan memberikan kredit atau pinjaman uang dengan bunga yang tinggi. Sedangkan klien yaitu nelayan Kenjeran ini berkepentingan mendapatkan jaminan sosial ekonomi berupa pinjaman uang disaat situasi yang susah, bantuan barang atau keperluan alat tangkap.

Hubungan patron-klien ini terus menerus berlangsung lama. Awalnya hubungan patron-klien ini dijalankan dengan intensitas yang jarang, artinya nelayan Kenjeran membutuhkan bantuan dari patron hanya pada saat tertentu saja, seperti pada saat mendaftarkan anaknya sekolah dan kegiatan incidental lainnya. Namun sejak adanya perubahan ekologi menyebabkan menurunnya hasil tangkapan nelayan, maka jalinan patron-klien ini semakin sering dimanfaatkan nelayan untuk menjamin kelangsungan hidupnya.

\section{Penganekaragaman Alat Tangkap}

Strategi berikutnya yang dilakukan oleh nelayan Kenjeran adalah menganekaragamkan alat tangkapnya. Terdapat beberapa alat tangkap digunakan oleh nelayan Kenjeran dengan kondisi cuaca yang tidak menentu dan musim panen ikan yang tidak pasti. Biasanya nelayan Kenjeran menggunakan penganekaragaman alat 
tangkapnya dengan menyesuaikan musim dalam menangkap hasil lautnya. Beragamnya jenis alat tangkapnya dan ukuran akan menyebabkan bervariasi pula teknik yang digunakan untuk menangkap ikan. Menurut (Badjeck, 2010) kapasitas untuk cepat beradaptasi terhadap perubahan ekologis melalui penggunaan teknik tangkap dan alatalat merupakan faktor yang sangat berpengaruh terhadap matapencahariaan nelayan.

Minimnya teknologi penangkapan dan akses informasi mengenai jenis alat tangkap yang ideal digunakan pada saat-saat tertentu menyebabkan nelayan biasanya mengganti alat tangkapnya berdasarkan informasi dari sesama nelayan. Alat tangkap nelayan Kenjeran menggunakan alat tangkap tradisional yang bervariasi, seperti alat tangkap kepiting laut dan darat, alat tangkap udang rebon, alat tangkap ikan beranak, dan masih banyak lagi. Dengan alat tangkap yang bervariasi ini nelayan Kenjeran mengikuti musim hasil laut yang ada, saat dimana musim hasil laut yang sedang banyak maka alat tersebut yang akan digunakan oleh nelayan Kenjeran. Biasanya hasil tangkapnya akan di jual ke pengepul ikan, hasil dari panen yang dijual ke pengepul tersebut digunakan untuk kebutuhan sehari-harinya. Hasil yang didapat biasanya tergantung banyaknya hasil panen ikan yang didapat oleh nelayan kisaran dua ratus hingga tiga ratus seribu, penghasilan nelayan Kenjeran ini tergantung dari pengepul akan menaikan harga atau tidak. Hasil penjualan tergolong pas-pasan setidaknya bagi nelayan cukup untuk kebutuhan pembiayaan anak untuk sekolah.

\section{Mobilisasi Rumah Tangga}

Dalam memenuhi kebutuhan hidup yang selalu dihadapi oleh keluarga atau rumah tangga adalah bagaimana individu-individu yang ada didalamnya harus berusaha maksimal dan bekerja sama untuk memenuhi kebutuhan rumah tangga sehingga kelangsungan hidupnya terpelihara. Mobilisasi rumah tangga nelayan diartikan sebagai kegiatan yang mengikutsertakan anggota rumah tangga nelayan untuk bekerja baik sektor perikanan maupun diluar sektor perikanan.

Menurut (Andrianti, 2012) salah satu strategi adaptasi yang dilakukan didalam rumah tangga nelayan untuk mengatasi kesulitan ekonomi yaitu dengan mendorong para istri mereka untuk ikut mencari nafkah. Kontribusi perempuan dalam memenuhi kebutuhannya sangat membantu pekerjaan seorang nelayan. Perempuan-perempuan yang terlibat dalam aktivitas mencari nafkah merupakan seseorang yang dianggap penting dalam perubahan perekonomian seorang nelayan.

Dalam memenuhi kebutuhan rumah tangga, peranan istri cukup penting. Para istri nelayan bertugas sepenuhnya dalam mengatur pengeluaran rumah tangga dalam kehidupan sehari-hari berdasarkan tingkat penghasilan yang diperoleh. Pekerjaan yang dilakukan oleh istri nelayan Kenjeran untuk membantu perekonomian keluarganya adalah dengan ikut kerja pada orang yang memiliki usaha ikan asin disini istri nelayan memasarkan hasil ikan yang sudah diolah menjadi makanan berupa kerupuk, selain itu juga menjadi pengelola hasil ikan seperti membersihkan sisik ikan dan membuka tempurung kerang sekaligus mengeluarkan isi kerang, pencari teripang, pembantu rumah tangga, serta pengolahan hasil ikan seperti mengasinkan ikan dan mengasapi ikan. Pada umumnya, bervariasinya pekerjaan yang dilakukan oleh seorang istri nelayan masih tidak jauh dengan sektor hasil laut melainkan perikanan. Hasil kerja seorang istri nelayan akan menambah keuangan rumah tangga, karena pendapatan yang diperoleh suami belum cukup dalam memenuhi sebuah kebutuhan hidup sehari-hari.

Istri nelayan di Kenjeran tidak hanya melakukan kegiatan domestik tetapi juga melakukan pekerjaan sampingan yang dapat menambah penghasilan rumah tangganya. 
Pada kegiatan membuat kesenian dari cangkang keong pantai dimana mereka membuat kesenian tersebut dihargai Rp. 10.000 hingga Rp. 20.000 per barang. Didalam sebuah kegiatan usaha ekonomi lainnya, beberapa istri nelayan juga ada yang membuka warung kecil yang menjual minuman di daerah pantai Kenjeran dan membuat hasil kesenian yang lainnya.

\section{Kesimpulan}

Bedasarakan hasil pembahasan dari tujuan penelitian ini dapat disimpulkan bahwa bentuk perubahan ekologis yang dirasakan oleh nelayan di Kenjeran adalah meliputi perubahan pada ekosistem laut yang disebabkan karena fluktuasi alam yaitu perubahan alam yang terjadi pada saat melaut. Perubahan ekologis yang dirasakan oleh nelayan Kenjeran berpengaruh pada kehidupannya sehingga dampak sosial ekonomi yang dirasakan oleh nelayan Kenjeran adalah dengan menurunnya hasil laut yang didapat oleh nelayan Kenjeran. Dengan pekerjaan yang bergantung pada lingkungannya menjadikan nelayan Kenjeran harus melakukan strategi adaptasi dalam memenuhi kebutuhan sehari-harinya yang lebih didominasi oleh pola adaptasi yang sifatnya reaktif. Strategi adaptasi yang dilakukan oleh nelayan adalah seperti diversifikasi pekerjaan, strategi penganekaragaman alat tangkap, strategi memanfaatkan hubungan sosial, dan strategi mobilisasi anggota keluarganya. 


\section{Bibliography}

Alfiasari, M. (2009). Modal Sosial dan Ketahanan Rumah Tangga Miskin di Kecamatan Tanah Sereal dan Kecamatan Bogor Timur, Kota Bpgor. Jurnal Sodality vol. 03, No. 01 .

Allison, E. E. (2001). The livelihoods approach and management of small-scale fishers. Marine Policy , 377-388.

Andrianti, R. (2012). Antropologi Maritim. Surabaya: Revka.

Badjeck, M. e. (2010). Impacts of elimate variability and change on fishery-based livehood. Journal of Marine Policy, 34 , 375-383.

Bennet, J. W. (1976). The Ecological Transition: Cultural Anthropology and Human Adaption. England: Pergamon Press Ltd.

Gerungan, W. (2009). Psikologi Sosial. Bandung: PT Refika Aditama.

Hamdani, H. \&. (2013). Faktor Penyebab Kemiskinan Nelayan Tradisional (The Factor Of Poverty Causes Traditional Fisherman). Artikel Ilmiah Hasil Penelitian Mahasiswa .

Hardiyanti, F. (2016). Konsep Perancangan Kampung Baru Nelayan Kenjeran Surabaya Berbasis Potensi Wilayah. Sains dan Seni ITS, Th. 5(2) , 293-298.

Imron, M. (2003). Kemiskinan Dlama Masyarakat Nelayan. Masyarakat dan Budaya, Th 5(1) , 1-20.

Nurisnaeny, P. S. (2016). Adaptasi Nelayan Kawasan Perbatasan Di Desa Sei Pancang Kecamatan Sebatik Utara Kabupaten Nunukan Provinsi Kalimantan Tengah. Journal Communicate Volume 1 (2) .

Retno, A. (2016). Kmebali Melaut: Industri dan Jasa Maritim dalam Visi Poros Maritim Dunia. . Kementrian Koordinator Bidang Kemaritiman RI dan PUSHANKAM UPN "Veteran". Yogyakarta , 69-82.

Smith, K. (1985). The Teritorial Dimension Of The State. London: Publishing House.

Surur, F. (2015). Strategi Adaptasi Nelayan Terhadap Perubahan Ekologis Danau Tempe di Desa Pallimae Kecamatan Sabbangparu Kabupaten Wajo. Jurnal Perencanaan Wilayah dan Kota , 100-102. 
Strategi Adaptasi Nelayan di Kenjeran, Kecamatan Sukolilo Larangan, Kabupaten Surabaya, Provinsi Jawa Timur dalam Menghadapi Ekologinya.

Tain, A. (2013). Faktor Dominan Penyebab Kemiskinan Rumah Tangga Nelayan Motor Tempel di Wilayan Tangkap Lebih Jawa Timur. Sosiohumaniora , 35-44.

Wiyono, E. S. (2008). Strategi Adaptasi Nelayan Cirebon, Jawa Barat. Billetin PSP. Vol XVII. No.3. Desember 2008 , 357-360. 